Trškan, D. (2017). Quality indicators, a new method for the evaluation of teaching practice in teacher education programmes in Slovenia: an example of quality indicators for school mentors - external mentors. Revista Electrónica Interuniversitaria de Formación del Profesorado, 20(2), 63-77.

\title{
Quality indicators, a new method for the evaluation of teaching practice in teacher education programmes in Slovenia: an example of quality indicators for school mentors - external mentors
}

\author{
Danijela Trškan \\ University of Ljubljana (Slovenia)
}

\begin{abstract}
The paper focuses on quality indicators for teaching practice which were created for the Faculty of Arts at the University of Ljubljana in the framework of the project "Quality of the University of Ljubljana" (2013-2014). So far there have been no systematic evaluations of the students' teaching practice for the entire Faculty of Arts. The aim of this paper is to evaluate the teaching practice of students, the role of school mentors, and the given method of determining quality indicators for all the participants in the process, namely school mentors, students, faculty mentors, faculty coordinators, and school coordinators at the Faculty of Arts. The Offering Quality Education to Adults Model was used as the method of determining quality indicators. The paper explains how quality indicators for the work of school mentors have been selected to aid in preparing efficient questionnaires and interviews which can help us assess the quality of teaching practice of students and plan measures for improvement. The results show that selected quality indicators for teaching practice are concrete and general enough to be used for an internal evaluation and quality assessment of any teaching practice and also in various teacher education programmes at universities across Slovenia and abroad.
\end{abstract}

\section{Key words}

Quality indicators; teaching practice; school mentors; self-evaluation.

Contacto:

Danijela Trškan, danijela.trskan@ff.uni-lj.si. Faculty of Arts, University of Ljubljana. Slovenia. 


\section{Indicadores de calidad, un nuevo método para la evaluación de la práctica docente en programas para la formación docente en Eslovenia: Ejemplo de indicadores de calidad para mentores escolares - mentores externos}

\section{Resumen}

El artículo se centra en indicadores de calidad para la práctica docente que fueron creados por la Facultad de Artes de la Universidad de Ljubljana en el marco del proyecto "Calidad de la Universidad de Ljubljana" (2013-2014). Hasta ahora no se habían realizado evaluaciones sistemáticas de las prácticas docentes para los estudiantes de toda la Facultad de Artes. El objetivo de este artículo es evaluar la práctica docente de los estudiantes, el papel de los mentores escolares y el método dado para determinar los indicadores de calidad para todos los participantes envueltos en el proceso, a saber: mentores escolares, estudiantes, mentores de la facultad, coordinadores de la facultad y coordinadores escolares de la Facultad de Artes. Se utilizó el Modelo para Adultos de Calidad de la Educación, como método para determinar los indicadores de calidad. El artículo explica cómo los indicadores de calidad para el trabajo de los mentores escolares han sido seleccionados para ayudar a la preparación de cuestionarios y entrevistas eficientes que nos puedan ayudar a evaluar la calidad de la práctica docente de los estudiantes y planificar medidas para mejorarla. Los resultados muestran que los indicadores de calidad seleccionados para la práctica docente son concretos y suficientemente generales para ser utilizados en una evaluación interna y en una evaluación de la calidad de cualquier práctica docente y también en diversos programas de formación docente en universidades de Eslovenia y del extranjero.

Palabras clave

Indicadores de calidad; práctica docente; mentores escolares; autoevaluación.

\section{Introduction to the role of teaching practice in university teacher education programmes in Slovenia}

In the initial training of future teachers in Slovenia, practical training is gaining prominence (Cvetek, 2005; Trškan et al., 2005; Peklaj, 2006; Kristl et al., 2007; Peklaj, 2007). Cvetek (2002) has found that teaching practice is seen less and less only as the application of the theoretical knowledge which the students gain from lectures at the faculty. During practice, students apply the theories they have been taught, use critical reflection, and develop their professional knowledge. According to Valenčič Zuljan and other authors (2006), competence-oriented training of students is gaining importance, whereas teaching practice (which has been incorporated into study programmes) should be well organised and didactically sensible.

In modern-day schools, the role of mentors is becoming more complex as it has a direct impact on the development of students - future teachers. For this reason, many studies and books have been written regarding the importance of school mentors during the practical training of students in Slovenia (Marentič-Požarnik et al., 2005; Valenčič Zuljan et al., 2005; Valenčič Zuljan et al., 2006; Valenčič Zuljan et al., 2007; Peklaj, 2007; GovekarOkoliš \& Kranjčec, 2010; Govekar-Okoliš et al., 2010a; Govekar-Okoliš et al., 2010b). 
At the Faculty of Arts of the University of Ljubljana, students - prospective teachers - can choose from the widest selection of courses, namely: andragogy, English, philosophy, French, geography, Greek, Italian, Latin, German, pedagogy, Polish, Russian, Slovak, Slovenian, sociology, Spanish and history. Each teacher education programme at the 2nd Bologna cycle (120 ECTS) comprises, in addition to subject courses, a pedagogical module worth 60 credit points (ECTS), which consists of the general part (24 ECTS) and the special part (36 ECTS). The general part comprises the following: psychology for teachers, didactics, pedagogy - theory of education, andragogy, observational practice for one week and one pedagogical elective course (Slovenian language for teachers, humanities and social sciences or research of the learning process). The special part comprises two courses: didactics of specific subject and teaching practice (Trškan, 2009; Peklaj, 2006).

All teacher education programmes incorporate a special course intended for the teaching practice of the selected school subject. All double-subject teacher education programmes at the Faculty of Arts have compulsory teaching practice of at least three weeks (6 ECTS), whereas the single-subject teacher education programmes have at least six weeks of teaching practice (12 ECTS). For example, during the teaching practice in history, students get used to systematically observing history lessons in elementary and secondary schools; connect their theoretical knowledge with practical pedagogical work; get used to planning, monitoring, carrying out and evaluating history lessons and extra-curricular activities; and develop a responsibility towards pedagogical work. After the teaching practice is concluded, students should be able to plan, organise, carry out and examine regular lessons and extra-curricular activities; use various teaching forms, methods and motivational techniques at various levels of education; draft, use and mark written, oral and authentic assignments; use teaching aids for history and information and communication technology; observe, monitor, evaluate and self-evaluate the teaching process. Most importantly, they should learn how to show satisfaction, responsibility and a positive attitude towards students, co-workers and pedagogical work in general (Trškan, 2009; Trškan, Komidar \& Hrovat, 2015). The Faculty of Arts has a joint coordinator and departmental coordinators for practical training. All school mentors take part in teaching practice voluntarily and based on cooperation agreements that schools have concluded with the faculty.

Several Slovenian authors have written about Slovenian teacher education programmes and the role of teaching practice (Juriševič et al., 2007; Javornik Krečič et al., 2007; Cvetek et al., 2009; Trškan, 2010; Valenčič Zuljan et al., 2011). The common characteristic of Slovenian teacher education programmes is that they are founded on a balanced combination of academic and research experience and practical experience. Teaching practice can be implemented in several ways: students observing the mentor; students collaborating with the mentor in carrying out the learning and other school activities; students carrying out lessons or other school activities independently, supervised by the mentor. Teaching practice is usually condensed practice, during which students work independently for a longer period of time.

Competences - important parts of teacher education programmes - are logically connected with professional competences, i.e. the competences of teachers. Razdevšek Pučko, Taštanoska \& Plevnik (2004) claim that students - prospective teachers - must acquire the competences they need to begin working at schools, and must simultaneously be aware of the need for further professional development throughout their teaching career.

The criteria for the accreditation of study programmes for educating teachers in Slovenia (Merila, 2011) specify the following competences which students should acquire in the study programmes of initial teacher education: efficient teaching and educating, 
cooperation with the working and social environment (with and within society), and qualification for professional development.

The internal self-evaluation procedures are of vital importance for assessing and improving the quality of the initial teacher education programmes. Možina \& Klemenčič (2008) state that self-evaluation is always a systematic procedure in which the educational organisation assesses its own quality. Based on this, it can plan and introduce the necessary improvements to its teacher education programmes at universities.

The aim of this paper is to explain how to prepare and select the quality indicators and use them in order to monitor the teaching practice of students and ensure its quality, which is the most important part of the teacher education programmes at the Faculty of Arts of the University of Ljubljana. This was also one of the main goals of the project "Quality of the University of Ljubljana" in 2013 and 2014, in which the Faculty of Arts strived to define the quality indicators for the self-evaluation of teaching practice in different study programmes.

Quality teaching practice requires eager participation from all of the participants in the process, namely from school mentors - external mentors, students, faculty mentors; internal mentors; faculty coordinators; and school coordinators. Even though all of the participants have an important role in the organisation and implementation of school practice, the paper focuses on the role, tasks and competences of mentors, who have the greatest impact on students during their teaching practice. We tried to establish which quality indicators can be used for the role, tasks and competences of the school mentors external mentors - before, during and after teaching practice, and how can we use them for self-evaluation.

We believe that the evaluation of the school mentors' work can be carried out based on quality indicators, whose main purpose is to monitor and assess quality. Also Musek Lešnik \& Bergant (2001 in Možina, 2010) explain that an advantage of such an evaluation is that it enables the setting of a content framework with select quality fields and concrete methods for conducting the self-evaluation in advance, and that the results of the evaluation can be compared directly with similar programmes.

In this paper the methodology and preparation of quality indicators are presented in the first phase, followed by the description of the selected quality indicators for school mentors - external mentors. Finally, the use of these indicators for self-evaluation is given.

\section{Methodology (quality indicators as an evaluation method)}

The evaluation of teaching practice has been carried out with the help of quality indicators, in accordance with the Offering Quality Education to Adults Model (Klemenčič et al., 2003; Možina et al., 2013), which is being used by the Slovenian Institute for Adult Education for improving the quality of adult education in Slovenia.

This is one of the rare models in Slovenia that systematically presents and carries out the self-evaluation of education by means of the following: quality indicators related to the subject of self-evaluation (which fields, subfields and indicators the self-evaluation will encompass); subjects taking part in the quality assessment processes; methods used for the assessment; results obtained by the assessment; and measures which have been introduced in order to improve quality (Klemenčič \& Možina, 2011). 
Several research methods (interviews, questionnaires, self-evaluation reports and documents) have been used for the selection, evaluation and use of quality indicators for teaching practice. The whole research has been divided into two phases.

In the first phase (in 2013), we analysed all teacher education programmes and course syllabi with teaching practice at the Faculty of Arts, as well as conducted several interviews with faculty coordinators, students, and school mentors in order to prepare the first draft of the potential quality indicators, where we defined the tasks of all participants.

In the second phase (in 2014), we prepared questionnaires for school mentors (75 school mentors), students (74 students), and faculty mentors (12), all of whom were involved in teaching practice in 2014 at the Faculty of Arts with the help of the first draft of the potential quality indicators. With the help of answers and results that suggested which indicators are important for the evaluation of teaching practice at the Faculty of Arts, we defined the self-evaluation fields, subfields, quality indicators and standards according to the Offering Quality Education to Adults Model.

We divided the quality indicators into six main fields:

- First self-evaluation field: roles, tasks, and competences of the student.

- Second self-evaluation field: roles, tasks, and competences of the school mentor external mentor.

- Third self-evaluation field: roles, tasks, and competences of the faculty mentor internal mentor.

- Fourth self-evaluation field: roles, tasks, and competences of the faculty coordinator.

- Fifth self-evaluation field: roles, tasks, and competences of the school coordinator.

- Sixth self-evaluation field: organisation, management and evaluation of teaching practice at the faculty and school level.

The first five fields relate to roles, tasks, and competences of all participants; the sixth field includes general indicators, which relate to the entire faculty or school organisation for teaching practice. All quality indicators include the preparation, activities related to teaching practice, and interaction between all participants (namely students, their school mentors and faculty mentors). We considered the active inclusion, communication and interaction of all participants and took into account the planning, implementation and evaluation of teaching practice, as well as, finally, the achievements of students. We included the initial, continuous and final reflections and satisfaction of all participants.

All of the quality indicators have been published in Quality Indicators of the Teaching Practice at the Faculty of Arts of the University of Ljubljana (Trškan, Komidar \& Hrovat, 2015).

In the next chapter only the final results of quality indicators for the second self-evaluation field - roles, tasks and competences of the school mentors - external mentors - are presented in detail as an example.

\section{Quality indicators for the role, tasks and competences of school mentors - external mentors}

Before we present the final selection of quality indicators, we have to provide some theoretical background which has also been important for the preparation and selection of quality indicators for school mentors. 
The more prominent role of mentors requires that school mentors master certain skills and possess the competences for modern-day mentoring. Marentič Požarnik (2006), who has held numerous seminars for school mentors, believes that mentors should master the methods of adult education; be able to determine the educational needs of the individual students; establish good personal and working relationships with the students; help the students with planning, carrying out and evaluating lessons; encourage them to reflect on their work; monitor and evaluate the students' achievements; give and receive feedback on lessons; manage time and stress properly; and ensure that the students get used to doing the same.

Javornik Krečič (2007) states that successful mentoring depends on the mentors' familiarisation with the study programme as well as with the individual students, since all school mentors should be well-acquainted with the students' competences acquired during teaching practice; should have an individualised approach towards the students; should provide constant feedback to the students regarding their progress and qualifications; should enable the students to learn about the foreseen and planned activities at the school; should encourage the students to assess their qualifications as teachers; and should be able to place themselves in the role of the students as prospective teachers. Successful mentors have to be familiar with innovations in the educational system regarding the system and its content; have to gain and preserve knowledge and skills relating to their own disciplines; have to reflect critically on their pedagogical approach and their relationships with students - prospective teachers; etc.

In 2009, the group for the revision of teacher education programmes in Slovenia specified and shaped the following competences of school mentors:

1) good didactic and methodical knowledge, which enables the teachers to plan and organise an optimal and stimulating learning environment with the intention of stimulating and facilitating the learning process in students;

2) qualification for teamwork (teaching) and cooperation with the other teachers and professional staff participating in the educational process;

3) a different role of teachers in the classroom, which requires greater knowledge of communication and organisation (teachers as mentors who organise independent or collaborative student work);

4) knowledge of psychology, enabling the mentors to get to know the students, their characteristics and peculiarities, which is required to effectively motivate, adapt and stimulate the learning processes;

5) training the students for lifelong learning in a knowledge society ('teaching them how to learn');

6) developing one's own professionalism: responsible guiding of one's own professional development in the lifelong learning process; and

7) using contemporary information and communications technology (ICT) in formal learning situations (during lessons) and in other professional work (also for the needs of one's own professional development). (Devljak \& Polak, 2009, p. 8).

Communication is the central activity during teaching practice, and it is a crucial one. The cooperation between mentors and students, communication and interpersonal relationships are delicate subjects and depend on the personality traits of mentors and students. Valenčič Zuljan and other authors (2007) consider respect, listening to others, acceptance of diversity, and awareness of interdependence in the communication process 
to be the foundations of a good interpersonal relationship. An important part of communication is feedback, which can be given throughout the practice or at its conclusion. Govekar-Okoliš \& Kranjčec (2010) suggest that mentors have to make sure to adjust the feedback to the students and to their ability to understand and change, and to provide them with feedback on time.

Tables 1, 2 and 3 give the final results of quality indicators for school mentors, which are divided into three subfields (Trškan, Komidar \& Hrovat, 2015, pp. 106-108). The quality subfields focus more precisely on the more specific aspects covered by a particular quality field. They define or steer the activities for assessing and developing quality in an individual quality field in greater detail (Možina et al., 2013). In the current example these subfields include the quality of teaching practice planning, implementation, and evaluation. The tables also indicate the quality standards (for each quality indicator) by means of statements describing the anticipated or desired quality.

Table 1.

First subfield - teaching practice planning

\begin{tabular}{|c|c|}
\hline Quality indicators for the school mentor & Quality standards \\
\hline Knowledge of the mentor's role. & $\begin{array}{l}\text { The school mentor is aware of the importance } \\
\text { of his/her role in teaching practice. }\end{array}$ \\
\hline $\begin{array}{l}\text { Knowledge of the teacher education } \\
\text { programme. }\end{array}$ & $\begin{array}{l}\text { The school mentor is familiar with the study } \\
\text { programme which the student is taking. }\end{array}$ \\
\hline $\begin{array}{l}\text { Knowledge of the course syllabus for the } \\
\text { teaching practice (content, goals, competences, } \\
\text { intended learning outcomes, assessment } \\
\text { methods). }\end{array}$ & $\begin{array}{l}\text { The school mentor is familiar with the course } \\
\text { syllabus which includes teaching practice } \\
\text { (content, goals, competences, intended } \\
\text { learning outcomes, assessment methods). }\end{array}$ \\
\hline $\begin{array}{l}\text { Knowledge of guidelines and material with } \\
\text { regard to the planning, implementation and } \\
\text { evaluation of the student's teaching practice. }\end{array}$ & $\begin{array}{l}\text { The school mentor is familiar with the } \\
\text { guidelines and has received the necessary } \\
\text { material for the planning, implementation and } \\
\text { evaluation of the student's teaching practice. }\end{array}$ \\
\hline $\begin{array}{l}\text { Planning and coordinating the time schedule for } \\
\text { the teaching practice with the student. }\end{array}$ & $\begin{array}{l}\text { The school mentor prepares an appropriate } \\
\text { time schedule for teaching practice with the } \\
\text { student and he/she is able to adjust his/her } \\
\text { work to the student's teaching practice. }\end{array}$ \\
\hline Informing the student. & $\begin{array}{l}\text { The school mentor informs the student of the } \\
\text { time schedule for teaching practice prior to its } \\
\text { beginning. }\end{array}$ \\
\hline $\begin{array}{l}\text { Informing the principal and the school } \\
\text { coordinator. }\end{array}$ & $\begin{array}{l}\text { The school mentor informs the school } \\
\text { coordinator and the school principal of the time } \\
\text { schedule for the student's teaching practice. }\end{array}$ \\
\hline Informing the faculty mentor. & $\begin{array}{l}\text { The school mentor informs the faculty mentor } \\
\text { of the time schedule for the student's teaching } \\
\text { practice. }\end{array}$ \\
\hline $\begin{array}{l}\text { Participation in the preliminary meeting of } \\
\text { school mentors at the faculty. }\end{array}$ & $\begin{array}{l}\text { The school mentor participates in the } \\
\text { preliminary meeting of all mentors at the } \\
\text { faculty prior to the beginning of the teaching } \\
\text { practice. }\end{array}$ \\
\hline
\end{tabular}


Table 2.

Second subfield - teaching practice implementation

\begin{tabular}{|c|c|}
\hline Quality indicators for the school mentor & Quality standards \\
\hline Preliminary meeting and talk with the student. & $\begin{array}{l}\text { The school mentor acquaints the student with } \\
\text { the time schedule for teaching practice at a } \\
\text { preliminary meeting. }\end{array}$ \\
\hline $\begin{array}{l}\text { Preliminary presentation of the school, } \\
\text { teachers and co-workers. }\end{array}$ & $\begin{array}{l}\text { The school mentor presents the school, school } \\
\text { facilities, teachers and co-workers to the student. }\end{array}$ \\
\hline $\begin{array}{l}\text { Continuous informing of the student of } \\
\text { potential changes to teaching practice. }\end{array}$ & $\begin{array}{l}\text { The school mentor offers up-to-date information } \\
\text { to the student on the potential changes to } \\
\text { teaching practice. }\end{array}$ \\
\hline Motivating and encouraging the student. & $\begin{array}{l}\text { The school mentor constantly motivates and } \\
\text { encourages the student for teaching and school } \\
\text { work. }\end{array}$ \\
\hline Mentor's professional help to the student. & $\begin{array}{l}\text { The school mentor offers advice and helps the } \\
\text { student to become introduced to the teaching } \\
\text { profession. }\end{array}$ \\
\hline Constant feedback to the student. & $\begin{array}{l}\text { The school mentor constantly offers feedback on } \\
\text { lesson plans, the lessons taught and other work } \\
\text { carried out by the student. }\end{array}$ \\
\hline $\begin{array}{l}\text { Continuous examination and evaluation of the } \\
\text { student according to the criteria prepared by } \\
\text { the faculty mentor. }\end{array}$ & $\begin{array}{l}\text { The school mentor constantly examines and } \\
\text { evaluates the work of the student according to } \\
\text { the criteria prepared by the faculty mentor for } \\
\text { lesson plans, lessons taught, etc. }\end{array}$ \\
\hline $\begin{array}{l}\text { Cooperation with the school coordinator and } \\
\text { the school principal. }\end{array}$ & $\begin{array}{l}\text { If necessary, the school mentor cooperates and } \\
\text { communicates with the school coordinator and } \\
\text { the school principal. }\end{array}$ \\
\hline Cooperation with the faculty mentor. & $\begin{array}{l}\text { The school mentor is able to cooperate and } \\
\text { communicate with the faculty mentor (by e-mail, } \\
\text { phone, etc.). The faculty mentor is always } \\
\text { available for questions. }\end{array}$ \\
\hline
\end{tabular}

Table 3.

Third subfield - teaching practice evaluation

\begin{tabular}{|l|l|}
\hline Quality indicators for the school mentor & Quality standards \\
\hline $\begin{array}{l}\text { Satisfaction of the school mentor with the } \\
\text { information received from the faculty on } \\
\text { planning the teaching practice. }\end{array}$ & $\begin{array}{l}\text { The school mentor is satisfied with preliminary } \\
\text { information on teaching practice, received from } \\
\text { the faculty mentor prior to the teaching } \\
\text { practice. }\end{array}$ \\
\hline $\begin{array}{l}\text { Satisfaction of the school mentor with the work } \\
\text { of the student. }\end{array}$ & $\begin{array}{l}\text { The school mentor is satisfied with the work of } \\
\text { the student during teaching practice because } \\
\text { the student respected all of the agreed } \\
\text { deadlines, showed a respectful attitude, took } \\
\text { advice and suggestions into account, } \\
\text { accomplished all of the planned assignments, } \\
\text { was involved in lessons and school activities } \\
\text { outside the obligatory part of teaching practice, } \\
\text { was professionally prepared for lessons, etc. }\end{array}$ \\
\hline
\end{tabular}




\begin{tabular}{|c|c|}
\hline $\begin{array}{l}\text { Satisfaction of the school mentor with the } \\
\text { cooperation with the school coordinator. }\end{array}$ & $\begin{array}{l}\text { The school mentor is satisfied with the } \\
\text { cooperation and communication with the } \\
\text { school coordinator. The school coordinator was } \\
\text { always available for questions. }\end{array}$ \\
\hline $\begin{array}{l}\text { Satisfaction of the school mentor with the } \\
\text { cooperation with the faculty mentor. }\end{array}$ & $\begin{array}{l}\text { The school mentor is satisfied with th } \\
\text { cooperation and communication with th } \\
\text { faculty mentor. The faculty mentor was alwa) } \\
\text { available for questions. }\end{array}$ \\
\hline $\begin{array}{l}\text { Satisfaction of the school mentor with the scope } \\
\text { and duration of teaching practice. }\end{array}$ & $\begin{array}{l}\text { The school mentor is satisfied with the amour } \\
\text { of assignments for the student (number } \\
\text { classroom observations, number } \\
\text { independent lessons, number of other scho } \\
\text { activities) and duration of teaching practice. }\end{array}$ \\
\hline $\begin{array}{l}\text { Satisfaction of the school mentor with the time } \\
\text { schedule and additional work during teaching } \\
\text { practice. }\end{array}$ & $\begin{array}{l}\text { The school mentor is satisfied with the tim } \\
\text { schedule for teaching practice. The mentor wo } \\
\text { able to coordinate the ongoing school wor } \\
\text { with the student's teaching practice. }\end{array}$ \\
\hline $\begin{array}{l}\text { Satisfaction of the school mentor with the } \\
\text { evaluation criteria. }\end{array}$ & $\begin{array}{l}\text { The school mentor is satisfied with th } \\
\text { evaluation criteria for student work, prepare } \\
\text { by the faculty mentor. }\end{array}$ \\
\hline $\begin{array}{l}\text { Mentor's evaluation of the student's acquired } \\
\text { general and subject-specific competences, } \\
\text { planned in the teacher education programme. }\end{array}$ & $\begin{array}{l}\text { The school mentor evaluates the student's } \\
\text { acquired general and subject-specific } \\
\text { competences, planned in the teacher education } \\
\text { programme, with a grade which adequately } \\
\text { reflects the student's acquired competences. }\end{array}$ \\
\hline $\begin{array}{l}\text { Mentor's evaluation of the student's achieved } \\
\text { goals, competences and learning outcomes, } \\
\text { planned in the course syllabus for teaching } \\
\text { practice. }\end{array}$ & $\begin{array}{l}\text { The school mentor evaluates the student's } \\
\text { achieved goals, competences and learning } \\
\text { outcomes, planned in the course syllabus for } \\
\text { teaching practice, with a grade which } \\
\text { adequately reflects the student's achieved } \\
\text { goals, learning outcomes and competences. }\end{array}$ \\
\hline $\begin{array}{l}\text { Mentor's grade of the student's teaching } \\
\text { practice. }\end{array}$ & $\begin{array}{l}\text { The school mentor evaluates the student's } \\
\text { teaching practice with a grade which } \\
\text { adequately reflects the work carried out by the } \\
\text { student. }\end{array}$ \\
\hline Reflection on mentorship. & $\begin{array}{l}\text { The school mentor regularly reflects on his/her } \\
\text { mentorship and endeavours to improve it. }\end{array}$ \\
\hline $\begin{array}{l}\text { Participation in the final meeting of school } \\
\text { mentors at the faculty. }\end{array}$ & $\begin{array}{l}\text { The school mentor participates in the } \mathrm{fi} \\
\text { evaluation meeting of all mentors at } t \\
\text { faculty. }\end{array}$ \\
\hline
\end{tabular}

The tables of indicators are designed to allow for the selection of quality indicators, depending on the specifics of the teaching practice at the school and the study programme.

\section{Use of quality indicators for self-evaluation}

Since quality indicators are useful for planning the self-evaluation of teaching practice (with interviews, questionnaires, etc.), an example of a questionnaire to obtain the opinion of school mentors on teaching practice is given below. 
The questionnaire could be drafted so as to include these eight sets:

- general information;

- evaluation of the faculty mentor;

- evaluation of the implementation of teaching practice;

- evaluation of students;

- evaluation of the general competences of students;

- evaluation of the competences of school mentors;

- evaluation of the teaching practice in general;

- evaluation of the poll.

In the first set, in addition to the general information about the school mentors (gender, length of service, professional title, employment), we would also be interested in the subject of the teaching practice that the students have attended; whether the school mentors have attended the training programme for mentors; and how they have become mentors to students.

In the second set, under "evaluation of the faculty mentor", we would be interested in whether the school mentors have received precise instructions and materials from the faculty mentors on how to organise the students' teaching practice; if they cooperated well with the faculty mentors (by e-mail, phone, etc.); whether the faculty mentors could always be reached in case of questions; and how suitable the criteria for evaluating the students attending teaching practice were. Furthermore, we would be interested in whether the faculty mentors have visited the school during the students' teaching practice and what the purpose of their visit was, or whether the faculty mentors have organised meetings (seminars or workshops) for school mentors (before or after the practice). Two openended questions could be added, related to the evaluation of the work of the faculty mentors - internal mentors; namely whether the school mentors could state some of their most positive observations and flaws, and suggest improvements to the work of the faculty mentors.

In the third set, under "evaluation of the implementation of teaching practice", we would mostly be interested in the suitability of the contents and scope of the practice. Thus, school mentors could assess the suitability of the design of teaching practice, the suitability of the number of lessons taught, of classroom observations and of other activities at the schools, which the students have had to carry out during practice. They could also assess the suitability of the duration and dates of the teaching practice. We would be interested in whether the school mentors have been able to adjust the daily school obligations to the students' teaching practice. In light of the fact that school mentors are already greatly burdened by pedagogical work, we would like to know which months of the year are not suitable for implementing teaching practice; how many hours on average they have devoted to planning the students' teaching practice; and how many hours per day, on average, they have invested in talks, reviewing lesson plans and providing feedback to the student. Two open-ended questions could be added, related to the evaluation of the implementation of teaching practice; namely if the school mentors could state some of their most positive observations and flaws, and suggest improvements to the implementation of teaching practice.

In the fourth set, under "evaluation of students", we would ask the school mentors to answer a set of questions for each student individually. We would be interested in how the school mentors evaluate the work of the students attending teaching practice; namely to what extent have the students complied with the agreed deadlines; whether they have had a respectful attitude during teaching practice; whether they have followed the advice and 
suggestions of mentors; carried out all of the planned requirements; been actively involved in lessons and school activities, even outside the obligatory part of teaching practice. We would like to know whether the students have prepared well for teaching lessons independently. Two open-ended questions could be added, related to the evaluation of the work of the student; namely if the school mentors could state some of their most positive observations and flaws, and suggest improvements to the work of the students.

In the fifth set, under "evaluation of the general competences of student", we would try to establish to what extent the teaching practice contributed to the development of general competences of students, as foreseen in each master's teacher education programme at the Faculty of Arts. School mentors could evaluate the following five sets of competences: the set of competences relating to effective teaching; the set of competences relating to knowledge assessment and to monitoring the progress of students; the set of competences relating to leadership and communication; the set of competences relating to broader professional competences; and the set of competences relating to lifelong learning.

In the sixth set, under "evaluation of the competences of school mentors", we would be interested in seeing to what extent the school mentors have made use of their competences. The following competences would be assessed on a five-point scale: the ability to motivate and encourage the students; give advice and provide help; communicate clearly; show empathy; detect the feelings, desires and needs of the student; plan the students' requirements; monitor the students regularly; and evaluate the students. The school mentors could add other competences that they have required in order to mentor the students.

In the seventh set, under "evaluation of the teaching practice in general", we would like to establish how satisfied the school mentors have been; how much satisfaction they have felt when helping and advising students; and how suitably qualified they have been to mentor the students who have attended practice. In the end, mentors could give suggestions for improving the teaching practice.

Since the quality work of school mentors requires constant training, the work of mentors can therefore be considered a lifelong process, involving constant reflection on the work performed. Therefore, the mentors' evaluation of teaching practice is of vital importance.

In the eighth set, under "evaluation of the poll", school mentors could evaluate how well the poll was designed, add additional topics which the poll could include, and suggest improvements to the poll. Thus the questionnaire could be improved further.

Finally, the list of selected quality indicators can be used for the self-evaluation - internal evaluation of teaching practice; namely for the type of teaching practice where students carry out teaching practice at schools independently (either in a condensed or dispersed manner) in various school subjects.

\section{Conclusions}

The Slovenian example of the self-evaluation and quality assessment of teaching practice, based on quality indicators and on feasible evaluation questionnaires, demonstrates new possibilities of collecting the data on quality and of determining the flaws in teaching practice in any education study programme. It contributes to the self-evaluation of different types of practical training at different faculties and universities. 
The quality indicators show that the quality of teaching practice implementation is influenced by many factors and depends on all teaching practice participants (students, mentors at schools, mentors at the faculty, faculty coordinators, and school coordinators). The successful organisation of teaching practice depends on the connection between faculties and schools. Its quality can be influenced by constant self-evaluation procedures based on quality indicators, as explained in the Offering Quality Education to Adults Model (Klemenčič et al., 2003; Možina et al., 2013).

As far as school mentors are concerned, we have established that qualified and eager school mentors are the central persons on whom the successful implementation of teaching practice depends. Therefore, school mentors also have a key role in promoting the professional development of students - prospective teachers. Assuring quality implementation of teaching practice requires, on the one hand, a precise plan of teaching practice and a description of the tasks before and during teaching practice, and, on the other hand, the self-evaluation of school mentors in the whole process. We have decided to divide the quality indicators for school mentors into three subfields (teaching practice planning, implementation, and evaluation) with corresponding quality standards (presented in tables).

The final conclusion is that anyone involved in the internal evaluation of teaching practice at the faculties can make use of the proposed quality indicators (for interviews, questionnaires, etc.) and, based on the results, prepare their own plan for those quality indicators in which they have detected flaws and the need for quality assessment and assurance. Možina (2007) believes that quality indicators enable the individuals' personal growth. We can conclude that with the prepared quality indicators the initial education of student teachers can be improved continuously.

\section{References}

Cvetek, S. (2002). Pedagoška praksa in njen pomen za izobraževanje učiteljev. [Teaching practice and its importance for teacher education.] Pedagoška obzorja [Educational horizons], 17(3-4), 125-139.

Cvetek, S. (2005). Poučevanje kot profesija, učitelj kot profesionalec. [Teaching as a profession, the teacher as a professional.] Radovljica: Didakta.

Cvetek, S. et al. (2009). Pedagoška praksa v luči partnerstva fakultet in šol v izobraževanju učiteljev po bolonjskih načelih. [Teaching practice in the spirit of partnership, faculties and schools of teacher education according to the Bologna principles.] Vzgoja in izobraževanje [Education], 40(3), 18-24.

Devljak, T. \& Polak, A. (2009). Nadaljnje izobraževanje in usposabljanje kot dejavnik razvoja učiteljevih kompetenc. [Further education and training as a factor for development of teacher competencies.] Vzgoja in izobraževanje [Education], 40(3), 5-12.

Govekar-Okoliš, M. \& Kranjčec, R. (2010). Izobraževanje mentorjev za praktično usposabljanje študentov po bolonjskih študijskih programih $v$ podjetjih/zavodih. [Training of trainers for practical training of students at Bologna study programmes in enterprises/institutions.] Ljubljana: Centre for Pedagogic Education of the Faculty of Arts, Academic Publishing Division of the Faculty of Arts. 
Govekar-Okoliš, M. et al. (2010a). Pogledi mentorjev na praktično usposabljanje študentov $v$ delovnih organizacijah. [Views of mentors on practical training of students in working organizations.] Ljubljana: Centre for Pedagogic Education of the Faculty of Arts, Academic Publishing Division of the Faculty of Arts.

Govekar-Okoliš, M. et al. (2010b). Praktično usposabljanje študentov v delovnih organizacijah in primeri praks. [The practical training of students in working organizations and examples of practices.] Ljubljana: Centre for Pedagogic Education of the Faculty of Arts, Academic Publishing Division of the Faculty of Arts.

Javornik Krečič, M. et al. (2007). Pomen mentorstva v času dodiplomskega izobraževanja in mentorjeve kompetence. [The importance of mentoring during undergraduate education and of mentor's skills.] Pedagoška obzorja [Educational horizons], 22(3-4), 3-62.

Juriševič, M. et al. (2007). Model praktičnega pedagoškega usposabljanja: od zasnove k izvedbi. [Model of practical pedagogical training: from design to performance.] In M. Juriševič et al. (eds.), Praktično pedagoško usposabljanje: Izhodišča - Model Izkušnje [Practical pedagogical training: Introduction - Model - Experience] (pp. 3158). Ljubljana: Faculty of Education.

Klemenčič, S. et al. (2003). Ponudimo odraslim kakovostno izobraževanje - Kazalniki kakovosti. [Offering quality education to adults - Quality indicators.] Ljubljana: Slovenian Institute for Adult Education. Retrieved August 21, 2013 from http://kakovost.acs.si/doc/N-461-1.pdf.

Klemenčič, S. \& Možina, T. (2011). Presojanje in razvijanje kakovosti v izobraževanju odraslih. [Quality assessment and development in adult education.] In S. Gaber \& Ž. Kos Kecojević (eds.), Kakovost $v$ šolstvu [Quality in education] (pp. 176-225). Ljubljana: Faculty of Education. Retrieved August 12, 2013 from http://www.solazaravnatelje.si/ISBN/978-961-6637-32-9.pdf.

Kristl, J. et al. (2007). Smernice za praktično usposabljanje na Univerzi v Ljubljani. [Guidelines for practical training at the University of Ljubljana.] Ljubljana: University.

Marentič-Požarnik, B. et al. (2005). Učitelji v prenovi - njihova strokovna avtonomija in odgovornost. [Teachers in the renovation - their professional autonomy and responsibility.] Ljubljana: Scientific Insititut of the Faculty of Arts.

Marentič Požarnik, B. (2006). Seminarji za mentorje kot priložnost za razvijanje kompetenc in poglabljanje refleksije ob partnerskem sodelovanju $s$ fakultetnimi učitelji. [Seminars for mentors as an opportunity to develop competencies and deepening reflection in partnership with the faculty teachers.] In C. Peklaj et al. (eds.), Teorija in praksa v izobraževanju učiteljev [Theory and practice in teacher education] (pp. 4552). Ljubljana: Centre for Pedagogic Education of the Faculty of Arts.

Merila za akreditacijo študijskih programov za izobraževanje učiteljev iz leta 2011. [Criteria for accreditation of study programmes for teacher education from 2011.] Retrieved May 4, 2013 from http://www.uradni-list.si/1/objava.jsp?urlid=201194\&stevilka=4013.

Možina, T. (2007). Merjenje zadovoljstva udeležencev v izobraževanju odraslih. [Participant satisfaction survey in adult education.] Ljubljana: Slovenian Institute for Adult Education. Retrieved August 21, 2013 from http://kakovost.acs.si/doc/N-467-1.pdf. 
Možina, T. \& Klemenčič, S. (2008). Razvoj kakovosti izobraževanja odraslih: notranje in zunanje presojanje kakovosti: zaključno raziskovalno poročilo o Oblikovanju nacionalnih standardov in kazalnikov kakovosti ter notranjem in zunanjem presojanju kakovosti $v$ izobraževanju odraslih. [Development of quality of adult education: Internal and outside quality assessment: Final research report on shaping the national standards and quality indicators, internal and outside quality assessment in adult education.] Ljubljana: Slovenian Institute for Adult Education. Retrieved August 21, 2013 from http://kakovost.acs.si/doc/N-464-1.pdf.

Možina, T. (2010). Kakovost kot (z)možnost. [Quality as ability and possibility.] Ljubljana: Slovenian Institute for Adult Education. Retrieved August 21, 2013 from http://kakovost.acs.si/doc/N-463-1.pdf.

Možina, T. et al. (2013). Kazalniki kakovosti izobraževanja odraslih. [Quality indicators for adult education.] Ljubljana: Slovenian Institute for Adult Education. Retrieved January 27, 2014 from http://kakovost.acs.si/doc/N-1028-1.pdf.

Peklaj, C. (Ed.). (2006). Teorija in praksa v izobraževanju učiteljev. [Theory and practice in teacher education.] Ljubljana: Centre for Pedagogic Education of the Faculty of Arts.

Peklaj, C. (Ed). (2007). Mentorstvo in profesionalna rast učiteljev. [Mentoring and professional development of teachers.] Ljubljana: Centre for Pedagogic Education of the Faculty of Arts.

Razdevšek-Pučko, C., Taštanoska, A. \& Plevnik, T. (2004). Kakovost izobraževanja s poudarkom na izobraževanju učiteljev in drugih izobraževalcev. [Quality education with an emphasis on the training of teachers and other educators.] Vzgoja in izobraževanje [Education], 35( 3), 27-31.

Resnik Planinc, T. \& Ilc, M. (2007). Pedagoška praksa. [Teaching Practice.] In C. Peklaj (ed.), Mentorstvo in profesionalna rast učiteljev [Mentoring and professional development of teachers] (pp. 59-74). Ljubljana: Centre for Pedagogic Education of the Faculty of Arts.

Trškan, D. et al. (2005). Pedagoška praksa pri specialnih didaktikah na Filozofski fakulteti. [Teaching practice in special didactics at the Faculty of Arts.] Ljubljana: Centre for Pedagogic Education of the Faculty of Arts.

Trškan, D. (ed.). (2009). Vloga za pridobitev soglasja k drugostopenjskemu pedagoškemu dvopredmetnemu študijskemu programu Zgodovina Filozofske fakultete Univerze $v$ Ljubljani (akreditacija študijskega programa). [Application for consent of the second cycle educational double-major study programme of History of the Faculty of Arts, University of Ljubljana (Accreditation of the study programme).] Ljubljana: Faculty of Arts.

Trškan, D. (2010). Izobraževanje in usposabljanje študentov zgodovine - bodočih učiteljev zgodovine na Filozofski fakulteti: prenovljeni pedagoški študijski programi. [Education and training of students of history - future teachers of history at the Faculty of Arts: renewed teacher education programmes.] Zgodovinski časopis [Historical Review], 64(3/4), 446-456.

Trškan, D., Komidar, L. \& Hrovat, L. (2015). Kazalniki kakovosti pedagoške prakse na Filozofski fakulteti Univerze $v$ Ljubljani. [Quality indicators of the teaching practice at the Faculty of Arts of the University of Ljubljana.] Ljubljana: Academic Publishing Division of the Faculty of Arts. 
Valenčič Zuljan, M. et al. (2005). Smernice pripravniku ob začetku profesionalne poti. [Guidelines for trainee at the beginning of his career.] Ljubljana: Faculty of Education. Ministry of Education and Sport.

Valenčič Zuljan, M. et. al. (2006). Učitelj mentor v sistemu pripravništva. [Teacher mentor in the apprenticeship system.] Ljubljana: Faculty of Education.

Valenčič Zuljan, M. et al. (2007). Izzivi mentorstva. [Challenges of mentor ship.] Ljubljana: Faculty of Education.

Valenčič Zuljan, M. et al. (2011). Sistemski vidiki izobraževanja pedagoških delavcev. [Systemic viewpoints on education of teachers.] Ljubljana: Educational Research Institute. 